\title{
Developmental Characteristics of Word Decoding and Text Reading Fluency among Korean Children with Developmental Dyslexia
}

\author{
Soyeong Pae ${ }^{a}$, Gayoung Shin ${ }^{\mathrm{b}}$, Ahyoung Seol ${ }^{\mathrm{c}}$ \\ ${ }^{a}$ Division of Speech Pathology \& Audiology, Audiology \& Speech Pathology Research Institute, Hallym University, Chuncheon, Korea \\ ${ }^{b}$ Department of Speech-Language Pathology and Audiology, Graduate School of Hallym University, Chuncheon, Korea \\ 'Audiology E Speech Pathology Research Institute, Hallym University, Chuncheon, Korea
}

Correspondence: Soyeong Pae, $\mathrm{PhD}$

Division of Speech Pathology and Audiology, Hallym University, 1 Hallimdaehak-gil, Chuncheon 24252, Korea

Tel: +82-33-248-2214

Fax: +82-33-256-3420

E-mail: spae@hallym.ac.kr

Received: April 5, 2017

Revised: May 26, 2017

Accepted: May 31, 2017

This work was supported by the National Research Foundation of Korea Grant funded by the Korean Government (No. NRF-2013S1A5A2A03044158), and by Hallym Research Fund (No. HRF-201701012)
Objectives: This study investigated word decoding ability and text reading fluency among Korean elementary school children with developmental dyslexia (DD). Dyslexic children's developmental patterns among three grade groups were compared with those of typically developing children (TD). Methods: Fifty-eight DD (20 early, 18 middle, and 20 upper grade elementary schoolers) as well as 58 TD matched by grade, nonverbal intelligence, and listening comprehension ability participated in the study. Each child read an 80-part list, composed of 40 words and 40 nonwords, along with one grade-level text. Words and nonwords included 20 phoneme-grapheme correspondent (PGC) words as well as 20 phoneme-grapheme non-correspondent (PGNC) words. Results: Both DD and TD had higher performance on words and PGC words than nonwords and PGNC words. DD revealed a large gap in both word and text reading when compared with TD, although the gap between the two reading groups was narrower as grades got higher. However, DD showed a bigger gap in reading nonwords compared to meaning words. As for text reading fluency, DD took a longer time and read less accurately compared to TD, although the gap between DD and TD in error rate of the total number of syllables in the texts was narrower as grades got higher. Conclusion: It seems evident that Korean DD experience difficulties in the phonological decoding of new and novel words and in reading text fluently despite the relative consistency of Korean Hangeul. Further studies are needed to find possible subtypes of dyslexia in relation to phonological awareness, rapid automatized naming, orthographic knowledge, and morphological awareness.

Keywords: Developmental dyslexia, Korean, Word reading, Reading fluency, Phonological decoding, Nonwords
DSM-5 (American Psychiatric Association, 2013)에 따르면, 특정 학습장애 중 읽기장애는 단어해독 정확도(word reading accuracy), 읽기 속도 또는 유창성(reading fluency), 읽기 이해력(reading comprehension)의 세 하위 영역에서 구체적으로 파악할 수 있다. 발달 시기에 나타나는 난독증(dyslexia)은 DSM-5에 따르면 단어를 정확 하게 또는 유창하게 읽는데 어려움을 보이거나, 해독력 및 철자력이 부족하여 학습에 어려움을 느끼는 경우를 말한다. 물론 해독과 철 자 능력 이외에, 읽기 이해 및 수학적 추론력에 부가적인 어려움이
있는 지 살펴보는 것이 매우 중요하다. 난독증은 특정학습장애 중 읽기장애에 대한 대안적 용어이기도 한데, 특정학습장애는 지적장 애, 교정되지 않은 시각 및 청각문제, 운동 및 신경학적 장애, 학습 언어 수준 및 불충분한 교육으로 잘 설명되지 않는 경우를 말한다.

DSM-5에 의하면 읽기, 쓰기, 수학을 포함하는 학습장애의 출현 율을 5\%-15\%로 본다. 발달성 난독의 경우, 글자체계의 투명도에 따 라 상대적으로 높은 또는 낮은 출현율을 보인다. 영어처럼 자소-음 소 일치도가 상대적으로 낮은 경우 발달성 난독은 더 높은 빈도로 
보고되며(Shaywitz, Shaywitzs, Fletcher, \& Escobar, 1990), 이태리 어처럼 자소-음소 일치도가 상대적으로 높은 경우 발달성 난독은 더 낮은 빈도로 보고된다(Lindgren, De Renzi, \& Richman, 1985). 우리나라의 경우 아직 난독증 출현율에 대한 심도있는 연구는 없지 만, 약 $1 \%-5 \%$ 의 추정치를 보고하는 보도나 연구가 있다(EBS news, 2014; Kim, Kang, Woo, \& Byun, 2015). 가장 보수적으로 추정해 초 등 학령 아동의 $1 \%$ 라고 가정했을 때, 2017년 3월 현재 초등학생이 약 278 만 명임을 감안하면 약 3 만 명이 난독아동일 가능성이 있다. 그런데 난독증의 경우 훌륭한 직업을 가질 수 있으며, 창의성이나 공간 추론력 등에 장점이 있는 경우도 있다(Eide \& Eide, 2013)는 점을 고려할 때, 더더욱 난독증에 대한 관심과 지원이 절실하다.

읽기장애 연구자들은 발달성 난독을 읽기의 단순관점 모델(simple view of reading, SVR; Gough \& Tunmer, 1986)에 근거하여 언 어이해력이 좋음에도 불구하고 해독(decoding)면에서 약점을 가 지고 있는 것으로 본다(Aaron, Joshi, Boulware-Gooden, \& Bentum, 2008; Catts, Adolf, \& Weismer, 2006). 철자와 말소리를 연결 하여 해독하는 것, 즉 읽는 것에 어려움을 겪는 경우이다.

발달성 난독 아동이 해독을 어려워하는 것은 시각적인 요인보다는 음운적인 면에서 약점이 있기 때문이며(Vellutino, Fletcher, Snowling, \& Scanlon, 2004), 특히 무의미낱말(nonword)을 잘 해독하지 못하는 경향이 있다(Goswami, Ziegler, Dalton, \& Schneider, 2003; Manis, Seidenberg, Doi, McBride-Chang, \& Peterson, 1996; Rack, Snowling, \& Olson, 1992; Snowling, 1980; Ramus, 2003; Wimmer, 1996; Ziegler \& Goswami, 2005). 자소-음소 일치도가 다른 여러 언 어권의 발달성 난독 아동을 대상으로 연구한 결과, 언어보편적으로 의미낱말보다 무의미낱말에서 더 어려움을 보이고, 읽기유창성 즉 읽기 속도에서 수행력이 낮음이 여러 글자체계 아동에서 확인되었 다(Landerl, Wimmer, \& Frith, 1997; Ziegler, Perry, Ma-Wyatt, Ladner, \& Schulte-Korne, 2003). 음운처리에서의 약점은 단어해독에서 의 이중처리모형을 활용하여 설명하기도 한다(Ziegler et al., 2008) 또한 이 약점이 단어해독력에 영향을 주는 것으로 보고, 음운성 난 독(phonological dyslexia)이라는 난독증 하위 유형을 사용하기도 한다(Peterson, Pennington, Olson, \& Wadsworth, 2014; Peterson \& Pennington, 2015).

발달성 난독 초등학생의 읽기 발달을 연구하기에 앞서 일반 아동 의 단어해독력과 읽기유창성 발달을 살펴보자. 한국의 아동들은 이 미 초등학교 입학시기에 낱말 재인으로 본 단어해독 능력이 대단히 발전해 있는 것으로 보인다. Jeong (2015)은 초등학교 1학년 학생 100 명을 상, 중, 하 세 집단으로 나누어 발달 양상을 살펴보았다. 1 분당 정확하게 읽은 글자 수를 기준으로 상위 $16 \%$ 는 상 집단, 하위 $15 \%$
는 하 집단으로, 중간에 있는 아동은 중 집단으로 명명하였다. 중간 집단 아동들은 초등 1 학년 입학 직후인 3월에 14 개 자음 자소 이름 중 평균 13.34 개 이름을 알고 있어 자소 지식이 매우 높은 것으로 보 인다. 그리고 자소-음소가 일치하는 의미낱말(예: 시장)의 경우 $92 \%$ 의 정반응률을, 자소-음소가 일치하는 무의미낱말(예: 조번)의 경우 평균 77\%의 정반응률을 나타내었다. 자소-음소가 불일치하는 의미 낱말(예: 작문)의 경우 평균 $76 \%$ 의 정반응률을, 자소-음소가 불일치 하는 무의미낱말(예: 삭눈)의 경우 평균 $32 \%$ 의 정반응률을 나타내 었다. 이 연구에서는 하위 집단과상위집단의 읽기격차가자소-음소 가 일치하는 의미단어의 경우 $38 \%$, 자소-음소가 일치하는 무의미 단어의 경우 $65 \%$ 로 나타났는데, 이는 한글 읽기 능력에서 상당한 개 인차가 존재함을 나타낸다. 한국어 단어해독력은 학년이 올라감에 따라 발달한다(Kim \& Pae, 2011; Yoon, 2015, 2016). Kim과 Pae (2011) 의 결과를 보면, 자소-음소 일치 낱말의 경우 초등 저학년은 약 $94 \%$, 초등 중, 고학년은 약 $97 \%$ 의 정반응률을 보였고, 자소-음소 불일치 낱말의 경우 초등 저학년이 약 $55 \%$, 초등 중학년이 약 $67 \%$, 고학년 에서약 $73 \%$ 의 정확률을 보였다.

최근 한국어에서도 읽기유창성이 읽기 능력과 관련된 주요한 요인 임을 밝히는 연구들이 발표되었다(Kim, Kim, \& Kang, 2016; Yoon, 2015, 2016). Kim 등(2016)은 유창성, 단어해독, 읽기 이해의 세 가지 구성요소가 초등학생 읽기 구조를 기술하는 데 가장 적합한 모델임 을 확인하였다. Yoon (2016)은 초등학생의 학년이 올라갈수록 읽기 유창성이 읽기이해와 가장 상관이 높고 특히 문단글 읽기유창성이 읽기 이해력을 더 크게 예측하는 요인임을 강조하였다. 한국 초등학 생은 저, 중, 고학년으로 가면서 읽기유창성의 발달 특성이 정확성 과 오류 면에서 달라지는 것으로 보인다. Kim, Park과 Kim (2010)은 $1,3,5$ 학년 아동들을 대상으로 학년에 적절한 글감을 제공하여 분 당 어절수로 문단글 읽기유창성 발달을 살펴보았다. 이 연구에서 설 명문 유창성은 $1,3,5$ 학년으로 가면서 분당 평균 $69.0,67.06,102.86$ 어절을 읽는 수준으로 발달하였다. 오류 어절수는 설명문의 경우 1 학년 평균 4.77 개, 3,5 학년으로 가면서 평균 2.88 개 및 2.00 개인 것으 로 나타났다. 설명문의 경우, 1 학년에서 3 학년으로 가면서 오류 어 절 수가 유의미하게 줄었고, 3 학년에서 5 학년으로 가면서 분당 정확 하게 읽은 어절수가 유의미하게 증가한 것으로 나타났다. Ahn, Shin 과 Kwon (2002)은 1-3학년 아동의 구어 속도를 말하기와 읽기 과제 를 통해 측정하였는데, 저학년 아동은 분당 평균 176.67음절(64.07 어절)을 읽고, 149.30 음절(56.60어절)을 말하는 것으로 나타났다.

읽기장애와 관련한 국내 연구들은 대개 저성취 모델에 의하여 읽 기 하위 집단 아동을 중심으로 발달 특성을 비교하거나, 읽기능력 의 예측요인이 어떤 것인지 파악해 왔다(Chung, 2009; Kim \& Pae, 
2012). 선행연구들은 학습장애 또는 학습부진 아동과 단어해독과 철자에서 주 어려움을 보이는 발달성 난독증 아동이 일부 포함되었 을 가능성이 있으나, 발달성 난독만을 대상으로 한 연구는 찾기 힘 들다. 유독 한국에서는 발달성 난독증(developmental dyslexia)에 대한 연구가 매우 드물다. 난독 진단도구의 부족도 한국에서 난독 증 연구가 어려운 이유 중의 하나였다(Kim, Woo, \& Shin, 2015). 그 런데 특수교육과 언어병리에서 나온 진단도구들을 활용하여 이제 발달성 난독증에 대한 연구를 좀더 현실적으로 진행할 수 있게 되었 다(Kim, Kim, Hwang, \& Yoo, 2014; Pae, Kim, Yoon, \& Jang, 2015).

다른 언어권 선행연구 결과를 종합하면, 발달성 난독 아동은 무 의미낱말 해독력에서 수행력이 더 낮을 가능성이 있고, 발달적으로 자소-음소 일치도에 따라 수행력이 다를 가능성이 있다. 영어는 자 소-음소가 불일치하는 경우가 상대적으로 매우 많으므로 영어 사 용 난독 아동이 자소-음소 일치도가 높은 비영어(예: 이태리어) 난 독 아동 보다 해독의 어려움을 더 많이 겪을 가능성이 높다(Ziegler et al., 2003; Ziegler \& Goswami, 2005). 한국어는 철자 깊이(orthographic depth)가 영어에 비해 상대적으로 얕아 음소 단위의 읽기 가 상대적으로 쉬울 수 있다. 따라서 단어해독뿐 아니라 읽기유창 성 면에서 발달적 특성을 살펴볼 필요가 있다.

Ziegler와 Goswami (2005)는 여러 언어들에서 나타나는 읽기습 득과 발달성 난독증을 이해하기 위해 심리언어학적인 구성소 이론 (grain size theory)을 제안하였다. 특히 특정 글자체계 안에서 여러 다른 발달 경로를 관찰할 수 있을 것으로 예측한다. 이 이론은 각 글자체계에서 발달이나 난독을 이해하기 위한 구성소를 찾아내는 것이 중요하다고 본다. 특히, 자소-음소 일치도가 높은 언어의 경우 음소 단위 구성소가 보다 활발하게작동할 것으로 본다.

이 연구에서는 지능과 언어 면에서 정상범주에 있으나, 전반적 읽기지수에서 -1 표준편차 이하에 위치한 발달성 난독 초등학생을 대상으로, 이들의 단어해독력과 문단글 읽기유창성이 학년이 올라 감에 따라 어떤 발달 양상을 보이는 지 일반 아동과 비교 대조하고 자 한다. 특히 의미 유무 요인 및 자소-음소 일치 요인이 학년집단 (초등 저, 중, 고)과 읽기집단(일반 대 난독)의 두 요인과 어떤 양상 을 보이는 지 확인한다. 그리고 문단글 읽기유창성을 10 초당 정확 하게 읽은 음절수, 오류율을 종속 변인으로 하여, 학년집단과 읽기 집단에 따라 어떤 차이가 있는 지 살펴보고자 한다.

\section{연구방법}

\section{연구대상}

본 연구는 서울, 경기, 강원, 경상 지역 초등학교에 재학 중인 1-6
학년 난독 아동 58 명과 학년을 일치시킨 일반 아동 58 명을 대상으 로 하였다. 집단별로 저학년(1-2학년) 20명, 중학년(3-4학년) 18명, 고학년(5-6학년) 20명이 속하였다.

난독 아동은 DSM-5의 임상 권고에 따른 특정학습장애 중 읽기 장애 아동을 대상으로 하였다. 전반적인 지능과 언어 면에서는 정 상범주에 있으나, 전반적인 읽기지수에서 - 1 표준편차 이하에 위치 한 발달성 난독 초등학생을 대상으로 하였다. 표준화검사인 한국 어 읽기검사(KOLRA; Pae et al., 2015)에서 단어해독, 읽기유창성, 읽기이해력을 포함하는 읽기지수 2 의 표준점수가 85 이하인 아동 이다. 한국어 읽기검사 듣기이해에서 백분위수 20 이상으로 일반적 표현 담화 언어력에서 어려움이 없는 아동들이며, 수용어휘력검사 (REVT; Kim, Hong, Kim, Jang, \& Lee, 2009)에서 10\%ile 이상에 해당되는 아동으로 선정하였다. 또한 부모 보고에 의해 충분한 읽 기 교육력을 지녔음에도 불구하고, 읽기 쓰기 관련 학업을 힘들어 하는 아동들이다. 일반 아동은 한국어 읽기검사의 읽기지수 2 가 표 준점수 90 이상, 듣기이해검사가 백분위수 20 이상이며, 수용어휘 력검사에서 $10 \% \mathrm{ile}$ 이상에 해당되어 읽기 언어 면에서 발달상 어려 움이 없는 아동으로 선정하였다.

연구대상은 모두 비언어성 지능지수가 80 이상에 속하는 아동이 며, 감각적, 신경학적 문제가 없으며, 정서 및 행동상 문제가 없음을 부모 또는 교사를 통해 확인하였다. 또한 두 집단 간 지능지수, 듣기 이해력의 차이를 검증하기 위해 독립표본 $t$-검정을 실시하였다. 실 시 결과, 한국 비언어성 지능검사(K-CTONI-2; Park, 2014)의 지능 지수와 한국어 읽기검사의 듣기이해 수행력이 통계적으로 차이가 없는 집단임이 확인되었다 $(t=1.893, p>.05 ; t=1.764, p>.05)$. 연구 대상의 정보는 Table 1 과 같다.

Table 1. Participants' characteristics

\begin{tabular}{|c|c|c|c|}
\hline & $\begin{array}{l}\text { K-CTONI-2 } \\
\text { (SS) }\end{array}$ & $\begin{array}{l}\text { KOLRA (reading } \\
\text { quotient2) }\end{array}$ & $\begin{array}{l}\text { Listening compre- } \\
\text { hension (SS) }\end{array}$ \\
\hline \multicolumn{4}{|l|}{ Dyslexia group } \\
\hline $\operatorname{Low}(\mathrm{N}=20)$ & 102 (9.92) & $62.7(17.13)$ & 104.6 (9.57) \\
\hline Middle (N=18) & $97.25(15.52)$ & $69.7(20.6)$ & $101.1(6.96)$ \\
\hline $\operatorname{High}(\mathrm{N}=20)$ & $96.5(11.23)$ & $75.0(7.4)$ & 101 (9.22) \\
\hline \multicolumn{4}{|l|}{ TD group } \\
\hline Low (N=20) & $105.7(9.38)$ & $103.7(6.91)$ & $106.3(7.43)$ \\
\hline Middle (N=18) & $99.6(6.35)$ & $105.9(9.54)$ & $107.9(9.10)$ \\
\hline $\operatorname{High}(\mathrm{N}=20)$ & $98.6(10.24)$ & $102.9(7.92)$ & $104.8(7.67)$ \\
\hline
\end{tabular}




\section{검사도구}

\section{단어해독}

단어해독 검사는 한국어 읽기검사(KOLRA)의 하위 검사로, 2 음 절의 낱말을 소리 내어 읽는 과제이다. 의미낱말 40 문항, 무의미낱 말 40 문항으로 구성되었다. 의미낱말과 무의미낱말에는 자소-음 소 일치형 낱말이 각 20 개, 자소-음소 불일치형 낱말이 각 20 개씩 포함되어 총 80 문항으로 구성되었다. 첫 문항부터 읽기 시작하여 연속하여 5 개 문항에서 오반응을 보이는 경우 이를 한계선으로 보 고 검사를 종료하였다.

\section{문단글 읽기유창성}

문단글 읽기유창성 검사는 한국어 읽기검사(KOLRA)의 하위 검사로 아동에게 문단글을 제시한 후 얼마나 정확하고 빠르게 읽 었는지를 평가하는 과제이다. 학년에 따라 전체 글의 길이, 문장의 복잡성, 어휘 난이도 등이 조절된 문단글을 제공하였다. 1-2학년은 130음절로 구성된 '김밥만들기', 3-4학년은 358음절로 구성된 '산 과 바다’, 5-6학년은 737음절로 구성된 ‘의생활’을 사용하였다.

\section{자료분석}

\section{단어해독 점수}

단어해독검사에서 정확하게 읽은 낱말에 1 점을 부여하여 총점 을 산출하고, 낱말의 유형에 따른 점수를 산출하였다. 의미낱말, 무 의미낱말, 자소-음소 일치형 낱말, 자소-음소 불일치형 낱말 각 40 개 문항에 대한 점수와 자소-음소 일치 의미낱말, 자소-음소 일치 무의미낱말, 자소-음소 불일치 의미낱말, 자소-음소 불일치 무의미 낱말 각 20 개 문항에 대한 점수를 산출하였다.

\section{문단글 읽기유창성 점수}

문단글 읽기유창성검사에서 나타난 아동의 반응을 기반으로 10
초당 읽은 음절수, 오류율을 산출하였다. 10 초당 읽은 음절수는 정 확하게 읽은 음절 수를 전체 소요시간으로 나눈 뒤, 10 을 곱하였다. 오류율은 생략, 대치, 첨가, 반복, 수정의 전체 오류 수를 문단글의 총음절 수로 나누어 산출하였다.

\section{신뢰도}

본 연구에서는 전체 자료 중 $20 \%$ 를 무작위로 선정하여 두 명의 연구자 간 전사 및 분석 신뢰도를 측정하였다. 검사자 간 신뢰도 측 정 결과, 단어해독 전사 신뢰도 $97.6 \%$, 채점 신뢰도 $100 \%$ 이고, 문단 글 읽기유창성 전사 신뢰도 $96.5 \%$, 채점 신뢰도 $95.4 \%$ 였다.

\section{통계처리}

낱말의 의미 유무, 자소-음소 일치 유무에 따라 읽기 집단(난독, 일반) 및 학년 집단(저학년, 중학년, 고학년)에서 어떠한 차이를 보 이는지 분석하고자 읽기 집단, 학년 집단을 집단 간 변인으로, 낱말 의 의미 유무 및 자소-음소 일치 유무를 집단 내 변인으로 하는 반 복측정 포함 삼원분산분석(repeated three-way ANOVA: 읽기 집 단 $\times$ 학년 집단 $\times$ 일치 유무, 읽기 집단 $\times$ 학년 집단 $\times$ 의미 유무)을 2 회 실시하였다. 집단 간 변인에서 차이가 나타나는 경우는 사후분 석을 실시하였다. 또한 읽기 집단과 학년 집단에 따른 문단글 읽기 유창성 특성을 살펴보고자 이원분산분석(two-way ANOVA)을 실 시하였다. 모든 통계처리는 SPSS 22.0을 사용하였다.

\section{연구결과}

\section{단어해독}

\section{읽기 집단 및 학년 집단의 단어해독력 기술통계}

읽기 집단과 학년 집단에 대한 단어해독력 기술통계를 실시한 결 과는 Table 2 와같다. 실시 결과, 자소-음소 일치 의미낱말에서 학년

Table 2. Descriptive statistics based on decoding abilities

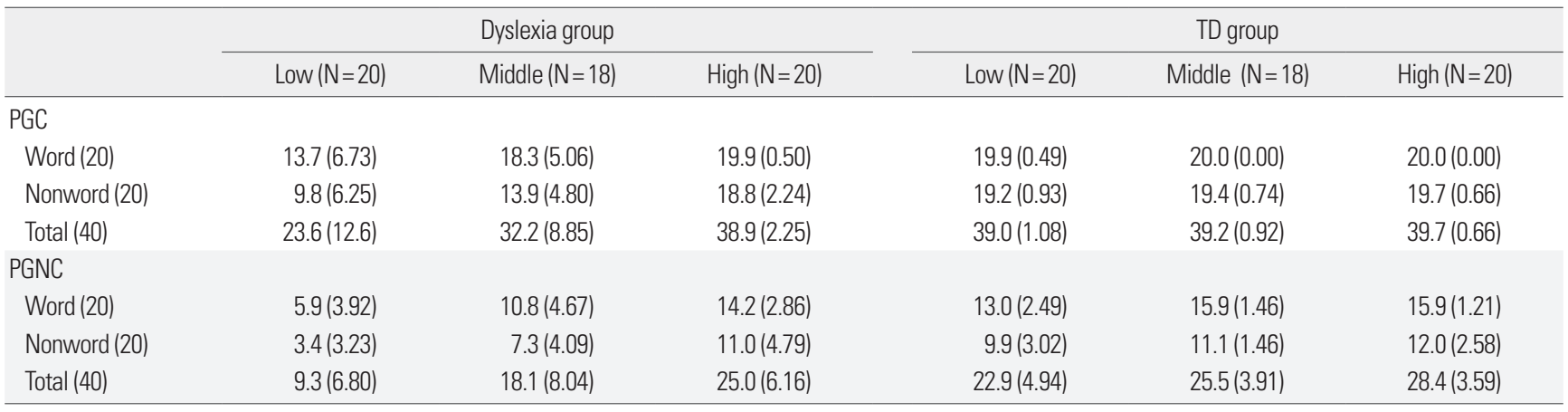

Values are presented as mean (SD).

$\mathrm{TD}=$ typically developing children; $\mathrm{PGC}=$ phoneme-grapheme correspondence; $\mathrm{PGNC}=$ phoneme-grapheme non-correspondence 
이 증가함에 따라난독아동은 13.7 (68.5\%), 18.3 (91.5\%), 19.9 (99.5\%), 일반 아동은 19.9 (99.5\%), $20.0(100 \%), 20.0(100 \%)$ 의 정반응을 보 였고, 자소-음소 일치 무의미낱말에서 난독 아동 9.8 (49\%), 13.9 (69.5\%), 18.8 (94\%), 일반 아동 19.2(96\%), 19.4 (97\%), 19.7 (98.5\%) 의 정반응을 보였다. 자소-음소 불일치 의미낱말에서 학년이 증가 함에 따라 난독 아동은 5.9 (29.5\%), 10.8 (54\%), 14.2 (71\%), 일반 아 동은 13.0 (65\%), 15.9 (79.5\%), 15.9 (79.5\%)의 정반응을 보였고, 자 소-음소 불일치 무의미낱말에서 난독 아동 3.4 (17\%), 7.3 (36.5\%), 11.0 (55\%), 일반 아동 $9.9(49.5 \%), 11.1(55.5 \%), 12.0(60 \%)$ 의 정반 응을 보였다.

\section{일치 유무, 읽기 집단, 학년 집단 간 수행력 차이}

낱말의 일치 유무에 따른 집단 및 학년의 수행력에 대한 기술통 계 결과는 Table 2 와 같다. 낱말의 일치 유무에 따라 집단과 학년 간 어떠한 차이를 보이는지 분석하기 위해 읽기 집단 $\times$ 학년 집단 $\times$ 일치 유무의 삼원분산분석을 실시하였다(Table 3). 분산분석 결 과, 읽기 집단, 학년 집단, 일치 유무에 따른 주효과가 유의미한 것으 로 나타났다 $(F=61.152, p<.001 ; F=29.236, p<.001 ; F=773.976$, $p<.001)$. 읽기 집단에 있어서는 일반 아동의 수행력이 더 높았고, 일치 유무에 있어서는 자소-음소 일치형 낱말 읽기의 수행력이 자

Table 3. Three-way ANOVA on reading group, grade group, PGC

\begin{tabular}{lrrrr}
\hline Factor & \multicolumn{1}{c}{ SS } & $d f$ & MS & $F$ \\
\hline Between groups & & & & \\
Reading groups & $3,646.502$ & 1 & $3,646.502$ & $61.152^{* * *}$ \\
Grade groups & $3,486.674$ & 2 & $1,743.337$ & $29.236^{* * *}$ \\
Reading groups $\times$ grade groups & $1,566.681$ & 2 & 783.341 & $13.137^{* * *}$ \\
Error & $6,559.300$ & 110 & 59.630 & \\
Within group & & & & \\
PGC & $11,172.622$ & 1 & $11,172.622$ & $773.976^{* * *}$ \\
PGC $\times$ reading groups & 2.489 & 1 & 2.489 & 0.172 \\
PGC $\times$ grade groups & 67.602 & 2 & 33.801 & 2.342 \\
PGC $\times$ reading groups $\times$ grade groups & 48.406 & 2 & 24.203 & 1.677 \\
Error & $1,587.889$ & 110 & 14.435 & \\
\hline
\end{tabular}

$\mathrm{PGC}=$ phoneme-grapheme correspondence; $\mathrm{SS}=$ sum of squares; $\mathrm{MS}$, mean square. ${ }^{* * *} p<.001$.
소-음소 불일치형 낱말 읽기의 수행력보다 높았다. 학년 집단에 대 한 사후분석에서는 저학년, 중학년, 고학년 간에 모두 유의한차이가 나타났다. 또한 읽기 집단과 학년의 상호작용 효과가 나타나 $(F=$ $13.137, p<.001)$ 저학년에서 난독과 일반 아동 간 격차가 가장 크고 고학년으로 갈수록 격차가 줄어들었다(Figure 1).

\section{의미 유무, 읽기 집단, 학년 집단 간 수행력 차이}

낱말의 의미 유무에 따른 집단 및 학년의 수행력에 대한 기술통 계 결과는 Table 4 와 같다. 낱말의 의미 유무에 따라 집단과 학년 간 어떠한 차이를 보이는지 분석하기 위해 읽기 집단 $\times$ 학년 집단 $\times$ 의미 유무의 삼원분산분석을 실시하였다(Table 5). 분산분석 결 과, 읽기 집단, 학년 집단, 의미 유무에 따른 주효과가 유의미한 것으 로 나타났다 $(F=60.349, p<.001 ; F=28.708, p<.001 ; F=235.911$, $p<.001)$. 읽기 집단에 있어서는 일반 아동의 수행력이 더 높았고, 의미 유무에 있어서는 의미낱말 읽기의 수행력이 무의미낱말의 읽 기 수행력보다 높았다. 학년 집단에 대한 사후분석에서는 저학년, 중학년, 고학년 간에 모두 유의한 차이가 나타났다. 또한 읽기 집단 과학년 간 $(F=13.743, p<.001)$, 의미 유무와 읽기 집단 간 $(F=8.079$, $p<.01)$ 상호작용 효과가 나타났다. 의미 유무와 읽기 집단 간 상호 작용 효과로 의미낱말보다 무의미낱말에서 일반 아동과 난독 아동

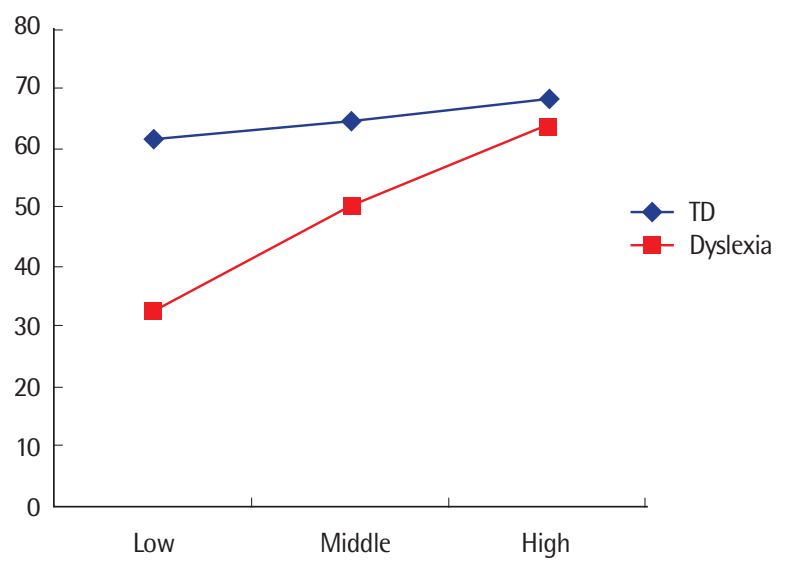

Figure 1. Decoding ability according to reading group and grade group. $\mathrm{TD}=$ typically developing children .

Table 4. Descriptive statistics based on meaning accessibility



Values are presented as mean (SD). $\mathrm{TD}=$ typically developing children. 
Table 5. Three-way ANOVA on reading group, grade group, MA

\begin{tabular}{lrrrc}
\hline Factor & SS & $d f$ & MS & $F$ \\
\hline Between groups & & & & \\
Reading group & $3,570.350$ & 1 & $3,570.350$ & $60.349^{* * *}$ \\
Grade group & $3,396.803$ & 2 & $1,698.402$ & $28.708^{* * *}$ \\
Reading group × grade group & $1,626.155$ & 2 & 813.078 & $13.743^{* * *}$ \\
Error & $6,507.800$ & 110 & 59.162 & \\
Within group & & & & \\
MA & $1,720.838$ & 1 & $1,720.838$ & $235.911^{* * *}$ \\
MAx reading group & 58.934 & 1 & 58.934 & $8.079^{* *}$ \\
MA× grade group & 39.441 & 2 & 19.721 & 2.704 \\
MA×reading group × grade group & 9.239 & 2 & 4.619 & 0.633 \\
Error & 802.389 & 110 & 7.294 & \\
\hline
\end{tabular}

$M A=$ meaning accessibility; $S S=$ sum of squares; $M S$, mean square.

${ }^{* *} p<.01,{ }^{* * *} p<.001$.

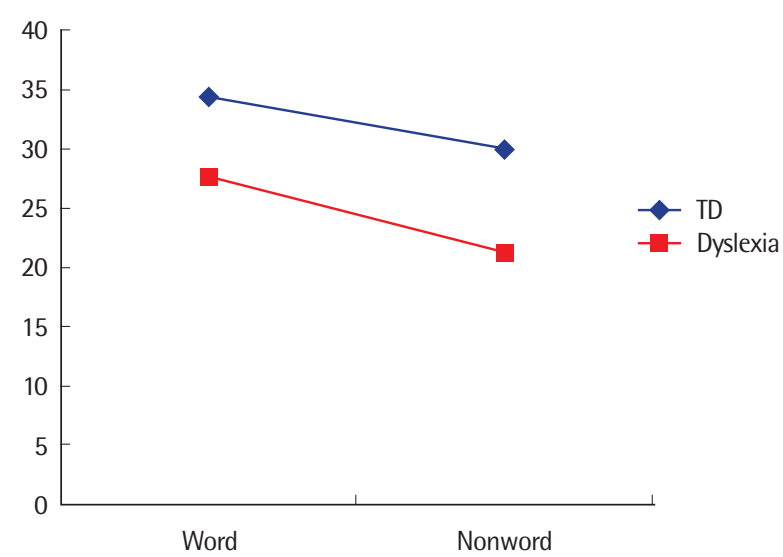

Figure 2. Decoding ability according to reading group and meaning accessibility. $\mathrm{TD}=$ typically developing children.

Table 6. Descriptive statistics based on number of correctly read syllables per 10 seconds

\begin{tabular}{lcc}
\hline & Dyslexia group & TD group \\
\hline Low $(\mathrm{N}=20)$ & $13.7(8.50)$ & $32.0(7.44)$ \\
Middle $(\mathrm{N}=18)$ & $25.4(8.36)$ & $42.2(9.25)$ \\
High $(\mathrm{N}=20)$ & $32.1(8.53)$ & $46.8(7.13)$ \\
\hline
\end{tabular}

Values are presented as mean (SD).

$\mathrm{TD}=$ typically developing children.

의 단어해독력 차이가 더 큰 것으로 나타났다(Figure 2).

\section{읽기유창성}

읽기 집단과 학년 집단 간 10 초당 정확하게 읽은 음절 수

읽기 집단과 학년 집단에 따른 10 초당 정확하게 읽은 음절 수의 기술통계는 Table 6 과 같다. 읽기 집단과 학년 집단에 따른 수행력
Table 7. Two-way ANOVA on reading group and grade group

\begin{tabular}{lrrrc}
\hline Factor & \multicolumn{1}{c}{$S S$} & $d f$ & MS & \multicolumn{1}{c}{$F$} \\
\hline Reading group & $7,428.084$ & 1 & $7,428.084$ & $110.598^{* * *}$ \\
Grade group & $5,170.926$ & 2 & $2,585.463$ & $38.495^{* * *}$ \\
Reading group × grade group & 61.312 & 2 & 30.656 & 0.456 \\
Error & $6,917.795$ & 103 & 67.163 & \\
\hline
\end{tabular}

$\mathrm{SS}=$ sum of squares; $\mathrm{MS}$, mean square.

${ }^{* * *} p<.001$.

Table 8. Descriptive statistics based on error rate

\begin{tabular}{lcc}
\hline & Dyslexia group & TD group \\
\hline Low $(\mathrm{N}=20)$ & $19.8(14.67)$ & $6.5(4.64)$ \\
Middle $(\mathrm{N}=18)$ & $12.2(8.00)$ & $5.7(3.24)$ \\
High $(\mathrm{N}=20)$ & $5.3(4.64)$ & $2.4(2.00)$ \\
\hline
\end{tabular}

Values are presented as mean (SD).

$\mathrm{TD}=$ typically developing children.

Table 9. Two-way ANOVA on reading group and grade group

\begin{tabular}{lrcrc}
\hline Factor & SS & $d f$ & MS & $F$ \\
\hline Reading group & $1,147.843$ & 1 & $1,147.843$ & $21.258^{* * *}$ \\
Grade group & $1,523.498$ & 2 & 761.749 & $14.107^{* * *}$ \\
Reading group x grade group & 476.059 & 2 & 238.029 & $4.408^{*}$ \\
Error & & & & \\
\hline
\end{tabular}

$\mathrm{SS}=$ sum of squares; $\mathrm{MS}$, mean square.

${ }^{*} p<.05,{ }^{* * *} p<.001$.

의 차이가 통계적으로 유의미한지 살펴보기 위해 이원분산분석을 실시한 결과는 Table 7과 같다. 분석 결과, 읽기 집단, 학년 집단의 주효과가 유의한 것으로 나타났다 $(F=110.598, p<.001 ; F=38.495$, $p<.001)$. 난독 아동보다 일반 아동의 수행력이 더 높았고, 학년 집 단에 대한 사후분석에서는 모든 학년 간 유의한 차이가 나타나 저 학년에서 고학년으로 갈수록 수행력이 높았다. 읽기 집단과 학년 집단 간 상호작용 효과는 통계적으로 유의미하지 않았다.

\section{읽기 집단과 학년 집단 간 오류율}

읽기 집단과 학년 집단에 따른 오류율의 기술통계는 Table 8과 같다. 읽기 집단과 학년 집단에 따른 수행력의 차이가 통계적으로 유의미한지 살펴보기 위해 이원분산분석을 실시한 결과는 Table 9 와 같다. 분석 결과, 읽기 집단, 학년 집단의 주효과가 유의한 것으 로 나타났다 $(F=21.258, p<.001, F=14.107, p<.001)$. 난독 아동보 다 일반 아동의 오류율이 낮았고, 학년 집단에 대한 사후분석에서 는 모든 학년 간 유의한 차이가 나타나 저학년에서 고학년으로 갈 수록 오류율이 감소하였다. 또한 읽기 집단과 학년 집단 간 상호작 용 효과가 나타났는데 $(F=4.408, p<.05)$, 저학년에서 난독과 일반 


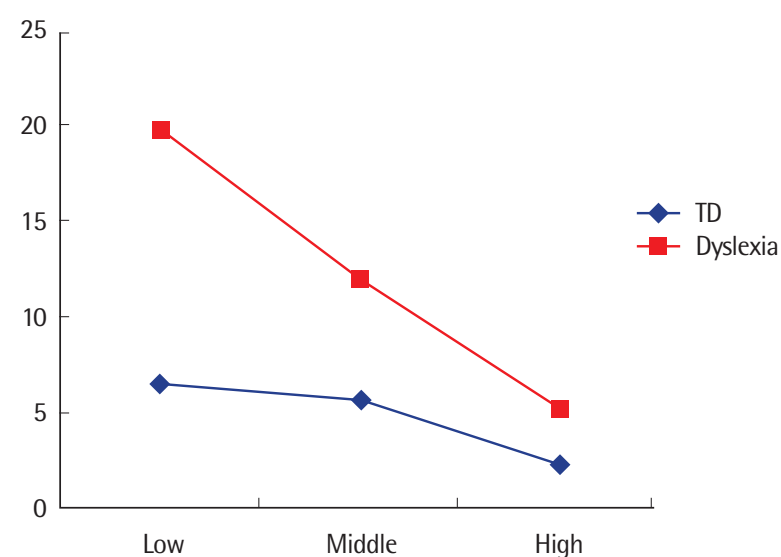

Figure 3. Error rate according to reading group and grade group. $\mathrm{TD}=$ typically developing children.

아동 간 오류율 격차가 가장 크고 고학년으로 갈수록 격차가 줄어 들었다(Figure 3).

\section{논의 및 결론}

한국어의 경우 자소-음소가 일치하는 의미낱말의 경우에, 일반 아동들은 초등 저학년부터 이미 $99 \%$ 의 정반응률로 천정에 도달한 모습을 보였다. 반면 난독 아동은 초등 저학년의 경우 약 $69 \%$, 중학 년의 경우 약 $92 \%$, 고학년의 경우 $99 \%$ 의 정반응률로, 초등 중, 고학 년에 가서야 천정에 도달한 양상을 보였다. 자소-음소가 일치하는 무의미낱말의 경우 일반 아동은 초등 저학년부터 평균 $96 \%$ 의 정 반응률을 나타낸 반면, 난독 아동은 초등 저학년의 경우 약 $49 \%$, 중학년의 경우 약 $70 \%$, 고학년의 경우 $94 \%$ 의 정반응률을 나타내 었다. 영어와 글자체계의 규칙성이 높은 다른 여러 언어권의 아동 을 대상으로 무의미낱말 해독력을 비교 연구한 Aro와 Wimmer (2003)의 결과를 참고로 보면, 한국 초등 저학년은 가장 수행력이 높았던 스웨덴 1학년 아동( $93 \%)$ 과 비슷한 결과를 나타내었다. 반 면에 영어를 습득하는 아동들은 무의미낱말을 1-2학년에 약 50\%$71 \%$ 정반응률을 보이는 것으로 나타났다. 한국 일반 아동은 초등 저학년임에도 불구하고 자소-음소가 일치하는 경우 평균 $98 \%$ 의 정반응률을 보였는데 이는 한국어 철자체계의 일관성 또는 투명도 로 인해 높은 단어해독능력이 나타났음을 시사한다.

자소-음소가 불일치하는 의미낱말의 경우에, 일반 아동들은 초 등 저, 중 고학년으로 가면서 $65 \%, 80 \%, 80 \%$ 의 정반응률을 보였다. 반면 난독 아동은 초등 저, 중, 고로 가면서 $30 \%, 54 \%, 71 \%$ 의 정반 응률을 나타내었다. 자소-음소가 불일치하는 무의미낱말의 경우 일반 아동들은 초등 저, 중 고학년으로 가면서 $50 \%, 56 \%, 60 \%$ 의 정
반응률을 보였고, 난독 아동은 초등 저, 중, 고로 가면서 $17 \%, 37 \%$, $55 \%$ 의 정반응률을 나타내었다. 자소-음소가 불일치하는 낱말들 의 정반응률은 자소-음소가 일치하는 낱말들에 비해 정반응률이 유의미하게 낮았다. 자소-음소가 불일치하는 경우 그것이 규칙적 이든 예외적이든 습득시간이 필요함을 알 수 있는데, 이는 단어해 독 발달에서 언어보편적으로 나타나는 현상으로 보인다(Cain, 2010).

한국의 발달성 난독 아동의 단어해독력은 일반아동에 비해 차 이가 매우 컸다. 초등 저학년 집단에서 일반 아동과의 격차가 가장 컸으며, 고학년으로 갈수록 격차가 줄어들었다. 자소-음소 일치유 무는 발달성 난독 아동과 일반 모두에서 비슷한 발달양상을 보였 다(Table 2, Figure 1). 읽기 집단과 학년 집단 변인 간에 유의미한 상 호작용 효과 $(F=13.137, p<.001)$ 가 나타났는데, 이는 초등 저학년 에 비해 초등 중학년, 초등 고학년으로 가면서 발달성 난독 아동과 일반아동의 수행력 차이가 $29 \%, 14 \%, 5 \%$ 로 줄어드는 데에 기인한 것으로 보인다. 의미유무는 발달성 난독 아동과 일반 아동의 단어 해독력에 다른 발달 패턴을 유도하였다. 의미낱말에 비해 무의미낱 말 해독에서 난독 아동과 일반 아동의 격차가 더욱 크게 나타났다

\section{(Table 4, Figure 2).}

초등 저학년 일반 아동은 자소-음소가 일치하는 낱말의 경우 의 미 유무에 상관없이 이미 $98 \%$ 의 정반응률을 보였다. 이는 자소-음 소를 빠르게 연결하여 읽을 수 있어 이미 천정에 도달한 현상을 보 인 것이다. 반면, 발달성 난독 아동은 자소-음소가 일치하는 낱말 의 경우 약 $59 \%$ 의 정반응률을 보였고, 무의미낱말의 경우 더욱 낮 은 정반응률을 보여 아직 자소와 음소를 대응시키는 것을 습득하 는 과정에 있음을 알 수 있다. 무의미낱말에서 수행력이 매우 낮았 던 점과, 초등 저학년에서 일반아동과 난독 아동의 격차가 크게 나 타난 결과는 ‘음운 해독에서의 약점(phonological decoding deficit)'(Ziegler et al., 2008)이 한국어를 습득하는 발달성 난독증 아동 에게도 적용됨을 시사하며, 음운형 난독(Peterson et al., 2014)이 한 국 아동들에게서 관찰될 수 있음을 지지한다.

한국 아동의 경우, 초등 저학년에서 중학년, 그리고 고학년으로 가면서 난독과 일반 아동의 단어해독력 격차는 크게 줄어드는 것 으로 나타났다. 초등 중(3-4)학년으로 가면서 자소-음소가 일치하 는 의미낱말은 일반아동과 차이가 나지 않았다 $(t=.920, p=.367)$. 초등 고(5-6)학년의 경우에는 자소-음소가 일치하는 의미낱말뿐 아니라자소-음소가 일치하는 무의미낱말에서도 일반아동과 유의 미한 차이가 없었다 $(t=1.811, p=.079)$. 따라서 자소-음소가 일치하 는 경우 한글 음소와 자소를 연결하는 데 대체로 큰 어려움이 없는 것으로 보인다.

흥미롭게도 초등학교 고학년의 경우에는 자소-음소가 불일치하 
는 경우 의미낱말에서는 두 집단 간 차이가 나타났고 $(t=2.429, p=$ $.021)$, 무의미낱말에서는 차이가 나타나지 않았다 $(t=.802, p=.428)$. 자소-음소 일치의 경우 의미 유무에 상관없이 해독력이 일반 아동 과 비슷하였고, 자소-음소가 불일치하는 무의미낱말에서도 일반 아동과 비슷한 것으로 미루어 보아 난독 아동의 단어해독력은 어 느 정도 안정된 것으로 보인다. 자소-음소가 불일치하는 즉 음운규 칙을 활용해서 의미낱말을 처리해야 하는 경우에는 일반 아동과 차이를 보였다. 이는 의미낱말에 노출된 빈도가 적거나 음운규칙 적용 자체의 숙련도가 낮았을 가능성이 있는 것으로 보인다. 저빈 도나 노출경험이 부족했다면 어휘 경로를 통해 한 눈에 낱말을 읽 을 수 없었을 것이고, 이는 한국어에서 표면성 난독(Peterson et al., 2014)에 대한 후속 연구가 필요함을 시사하는 내용이다.

한국의 발달성 난독 아동도 읽기 속도에서의 약점이 언어보편적 으로 확인되었다. 학년수준에 적절한 짧은 글을 읽는데 있어, 초당 정확하게 읽은 음절 수가 일반 아동에 비해 낮은 수행력을 나타내 었다. 초등 저, 중, 고학년 모두에서 낮은 수행력을 보였다. 초당 정확 하게 읽은 음절수로 측정했을 때, 일반아동들이 초등 저, 중, 고학 년으로 가면서 평균 $3.20,4.22,4.68$ 음절을 읽은 반면, 난독 아동들 은 초등 저, 중, 고로 가면서 평균 $1.37,2.54,3.21$ 음절을 읽었다. 일 반 아동에 비해 느리게 읽기는 하지만, 초당으로 추정하면 발달성 난독 아동들이 매우 느리게 읽는 것은 아님을 알 수 있다. 읽기유창 성이 읽기능력 측정에 매우 주요하고(Fuchs, Fuchs, Hosp, \& Jenkins, 2001), 한국어에서 발달성 난독 아동을 위해 매우 주요한 발 달추적요소가 될 수 있음을 시사한다.

일반 아동의 오류율이 초등 저, 중, 고로 가면서 $6.54 \%, 5.73 \%$, $2.38 \%$ 인 반면, 난독아동의 오류율은 $19.79 \%, 12.16 \%, 5.29 \%$ 로 나 타나 큰 편이다. 전체 음절수 대비 오류 음절수를 비율로 환산한 결 과, 난독아동은 오류율 면에서는 초등 저학년에서 고학년으로 가 면서 격차가 크게 줄어들지만 표준편차는 일반 아동에 비해 여전 히 큰 것으로 나타났다. 발달성 난독아동은 음운인식(phonological awareness) 및 빠른이름대기(rapid automatized naming) 등 음 운과 관련된 인지처리에서 약점이 나타나는 경우가 많다(McBrideChang \& Kail, 2002; Peterson \& Pennington, 2015). 난독 아동들 의 개인차가 매우 커 다양한 해독력과 속도를 가진 아이들이 어떤 이유로 어려움을 겪는 지 살펴볼 필요가 있다. 음운인식 능력과 빠 른이름대기가 한국의 발달성 난독증 하위유형을 설명해 줄 수 있 는 지 후속 연구가 필요한 것으로 보인다. 한국어의 경우 발달성 난 독 아동의 하위 유형(Ziegler et al., 2008)이 학년 또는 읽기수준에 따라 어느 정도로 어떻게 나타나는 지 살펴볼 필요가 있다.

결론적으로, 난독 아동은 일반 아동에 비해 무의미낱말의 경우
에 더 읽기 어려워하는 모습을 보였다. 이는 자소 음소에 대한 음운 적 경로 활성화가 매우 필요함을 시사하며 자소와 음소를 연결하 는 파닉스 접근법을 활용하는 것이 매우 중요함을 시사한다. 이러 한 내용은 난독 아동을 대상으로 한 다양한 언어권의 선행연구들 에서도 밝혀진 내용이다(Goswami et al., 2003; Rack et al., 1992; Snowling, 1980; Ramus, 2003; Wimmer, 1996; Ziegler \& Goswa$\mathrm{mi}, 2005)$.

읽는 속도에서의 차이도 한국의 발달성 난독 아동들에게 약점 으로 작용할 것으로 보인다. 한국어는 글자와 소리의 대응이 규칙 적인 표층표기체계 언어로 낱말 해독이 완성되는 시기가 빨라 정확 도뿐 아니라 속도를 함께 고려하는 것이 중요하다고 보고되고 있 다. 글을 읽고 새로운 정보를 이해하고 알고 있는 정보를 확장하는 것은 읽기속도와 정확도에 영향을 받게 된다. 선행연구에 의하면 글자와 소리의 대응이 규칙적인 표층표기체계 언어에서 읽기의 어 려움을 보이는 아동은 읽기 정확도보다 읽기 속도에서 어려움을 보인다고 하였다(Wimmer, Mayringer, \& Landerl, 2000). 따라서 발달성 난독 아동들에게 적절한 읽기유창성 촉진이 필요할 것으로 보인다.

언어권에 따라 난독 특성을 이해할 필요가 있다. 한글이 매우 과 학적이고 읽기 쉬운 글자체계임에도 불구하고, 이 연구는 한국에 서도 발달성 난독 학생이 존재함을 확인하였다. 자소-음소 일치도 가 높은 언어권의 경우 해독력이 상대적으로 높지만(Landerl et al., 1997), 일반 아동과의 격차가 크게 남을 확인하였다. 또한 이 연구 결과는 Ziegler와 Goswami (2005)의 심리언어학적인 구성소 이론 을 지지한다. 특히, 음소 단위 구성소가 자소-음소 일치도와 함께 중요함을 확인하였다. 구체적인 구성소들을 찾고 이 구성소들의 발 달경로를 추적하는 후속연구가 필요하다.

이 연구는 한국에서 발달성 난독 초등학생을 확인하였고, 단어 해독과 읽기유창성에서의 어려움을 구체적으로 확인하였다. 단어 해독에서 음운경로 활용과 읽기 속도의 지원이 시급함을 확인하였 다. 그런데 이 연구는 횡단적 연구이고 일반학생이 학년 일치 집단 이었다는 제한점을 지니고 있으므로, 해석에 주의가 필요하다. 발 달성 난독 아동에 대한 철자 지식이나 형태소 지식 및 인식력에 대 한 연구가 필요하고, 단어해독과 문단글 읽기에서 보인 실수와 발 달적 특성을 분석하여 구성소를 좀더 구체적으로 타당하게 제시할 필요가 있을 것이다. 이 연구에서는 말-언어장애, $\mathrm{ASD}$ 를 배제하고 특히 말-언어 능력에서 정상범주에 있는 아동들로 읽기에만 주 문 제를 가지는 아동들을 대상으로 하였다. 후속연구에서는 언어나 다른 동반장애 유무가 발달성 난독과 어떻게 상호작용하는지 후속 연구가 필요하다고 본다. 특히 후속 연구들을 토대로 발달성 난독 
아동의 잠재력을 최대화할 수 있는 실질적 지원책을 제공할 수 있 기를 기대한다.

\section{REFERENCES}

Aaron, P. G., Joshi, R. M., Gooden, R., \& Bentum, K. E. (2008). Diagnosis and treatment of reading disabilities based on the component model of reading: an alternative to the discrepancy model of LD. Journal of Learning disabilities, 41, 67-84.

Ahn, J., Shin, M., \& Kwon, D. (2002). The study of speech rate in normal-speaking adults and children. Speech Sciences, 9, 93-103.

American Psychiatric Association. (2013). Diagnostic and statistical manual of mental disorders; DSM-5 (5th ed.). Washington, DC: Author.

Aro, M., \& Wimmer, H. (2003). Learning to read: English in comparison to six more regular orthographies. Applied Psycholinguistics, 24, 621-635.

Cain, K. (2010). Reading development and difficulties. Oxford: Wiley-Blackwell.

Catts, H. W., Adlof, S. M., \& Weismer, S. E. (2006). Language deficits in poor comprehenders: a case for the simple view of reading. Journal of Speech, Language, and Hearing Research, 49, 278-293.

Chung, B. (2009). The relationship among short-term/working memory, phonological awareness, listening comprehension, and inferential skills of school-aged poor readers. Journal of Rehabilitation Research, 13, 313-327.

EBS News (April 28, 2014). http://home.ebs.co.kr/ebsnews/menu1/newsAllView/10215253/H?eduNewsYn=N\&newsFldDetlCd=\&brdcDt=\&dtBtn= $\& \operatorname{srchStartDt}=\& \operatorname{srchEndDt}=\& \operatorname{srchType}=\& \operatorname{srchWords}=\& \operatorname{srch} W o r d s 2=\& c$ Page $=705$

Eide, B. L., \& Eide, F. F. (2013). The dyslexia advantage: unlocking the hidden potential of the dyslexic brain (J. Jung, S. Kim, D. Park, \& S. Han, Trans.). Seoul: Sigma Press.

Fuchs, L. S., Fuchs, D., Hosp, M. K., \& Jenkins, J. R. (2001). Oral reading fluency as an indicator of reading competence: a theoretical, empirical, and historical analysis. Scientific Studies of Reading, 5, 239-256.

Goswami, U., Ziegler, J. C., Dalton, L., \& Schneider, W. (2003). Nonword reading across orthographies: how flexible is the choice of reading units? Applied Psycholinguistics, 24, 235-247.

Gough, P. B., \& Tunmer, W. E. (1986). Decoding, reading, and reading disability. Remedial and Special Education, 7, 6-10.

Jeong, J. (2015). An examination of changes in first graders' consonant-vowel naming, word recognition, and reading fluency. Journal of Elementary Ed- ucation, 28, 113-131.

Kim, A. H., Kim, U. J., \& Kang, E. Y. (2016). A confirmatory factor analysis on reading constructs across ages. Communication Sciences \& Disorders, $21,631-641$.

Kim, A., Kim U., Hwang, M., \& Yoo, H. (2014). Test of Reading Achievement and Reading Cognitive Processes Ability. Seoul: Hakjisa.

Kim, A., Park, S., \& Kim, J. (2010). Reading fluency of elementary students in Korea: reading development patterns and error patterns. Korean Journal of Communication Disorders, 15, 43-55.

Kim, M., \& Pae, S. (2011). The decoding development of Korean children in word reading. Korean Journal of Communication Disorders, 16, 143-153.

Kim, M., \& Pae, S. (2012). Reading skills and phonological processing abilities of Korean elementary school children with/without poor reading. Korean Journal of Communication Disorders, 17, 565-581.

Kim, Y. T., Hong, G. H., Kim, K. H., Jang, H. S., \& Lee, J. Y. (2009). Receptive \& expressive vocabulary test (REVT). Seoul: Seoul Community Rehabilitation Center.

Kim, Y., Kang, O., Woo, J., \& Byun, C. (2015). A study on standardizing a dyslexia screening checklist and statistical estimation of Korean students with dyslexia. Korea Journal of Learning Disabilities, 12, 21-45.

Kim, Y., Woo, J., \& Shin, J. (2015). A study on dyslexia research. Journal of Special Education: Theory and Practice, 16, 213-242.

Landerl, K., Wimmer, H., \& Frith, U. (1997). The impact of orthographic consistency on dyslexia: a German-English comparison. Cognition, 63, 315334.

Lindgren, S. D., De Renzi, E., \& Richman, L. C. (1985). Cross-national comparisons of developmental dyslexia in Italy and the United States. Child Development, 56, 1404-1417.

Manis, F. R., Seidenberg, M. S., Doi, L. M., McBride-Chang, C., \& Petersen, A. (1996). On the bases of two subtypes of development dyslexia. Cognition, 58, 157-195.

McBride-Chang, C., \& Kail, R. V. (2002). Cross-cultural similarities in the predictors of reading acquisition. Child Development, 73, 1392-1407.

Pae, S., Kim, M., Yoon, H. J., \& Jang, S. (2015). Korean Language Based Reading Assessment (KOLRA). Seoul: Hakjisa.

Park, H. (2014). Korean version of Comprehensive Test of Nonverbal Intelligence Second Edition (K-CTONI-2). Seoul: Mind Press.

Peterson, R. L., \& Pennington, B. F. (2015). Developmental dyslexia. Annual Review of Clinical Psychology, 11, 283-307.

Peterson, R. L., Pennington, B. F., Olson, R. K., \& Wadsworth, S. J. (2014). Lon- 
gitudinal stability of phonological and surface subtypes of developmental dyslexia. Scientific Studies of Reading, 18, 347-362.

Rack, J. P., Snowling, M. J., \& Olson, R. K. (1992). The nonword reading deficit in developmental dyslexia: a review. Reading Research Quarterly, 27, 2953.

Ramus, F. (2003). Developmental dyslexia: specific phonological deficit or general sensorimotor dysfunction? Current Opinion in Neurobiology, 13, 212-218.

Shaywitz, S. E., Shaywitz, B. A., Fletcher, J. M., \& Escobar, M. D. (1990). Prevalence of reading disability in boys and girls: results of the Connecticut Longitudinal Study. JAMA, 264, 998-1002.

Snowling, M. J. (1980). The development of grapheme-phoneme correspondence in normal and dyslexic readers. Journal of Experimental Child Psychology, 29, 294-305.

Vellutino, F. R., Fletcher, J. M., Snowling, M. J., \& Scanlon, D. M. (2004). Specific reading disability (dyslexia): what have we learned in the past four decades? Journal of Child Psychology and Psychiatry, 45, 2-40.

Wimmer, H. (1996). The nonword reading deficit in developmental dyslexia: evidence from children learning to read German. Journal of Experimental
Child Psychology, 61, 80-90.

Wimmer, H., Mayringer, H., \& Landerl, K. (2000). The double-deficit hypothesis and difficulties in learning to read a regular orthography. Journal of Educational Psychology, 92, 668-680.

Yoon, H. (2015). Prediction of reading comprehension in early and late elementary grades: contribution of word decoding, vocabulary, and syntactic knowledge. Communication Sciences \& Disorders, 20, 536-546.

Yoon, H. (2016). The role of reading accuracy and reading fluency in reading comprehension for school-aged children. Journal of Speech-Pathology \& Hearing Disorders, 25, 109-108.

Ziegler, J. C., \& Goswami, U. (2005). Reading acquisition, developmental dyslexia, and skilled reading across languages: a psycholinguistic grain size theory. Psychological Bulletin, 131, 3-29.

Ziegler, J. C., Castel, C., Pech-Georgel, C., George, F., Alario, F. X., \& Perry, C. (2008). Developmental dyslexia and the dual route model of reading: simulating individual differences and subtypes. Cognition, 107, 151-178.

Ziegler, J. C., Perry, C., Ma-Wyatt, A., Ladner, D., \& Schulte-Korne, G. (2003). Developmental dyslexia in different languages: language-specific or universal? Journal of Experimental Child Psychology, 86, 169-193. 


\section{국문초록}

\section{한국 발달성 난독 학생의 해독 및 읽기유창성 발달 특성}

배소영 ${ }^{1} \cdot$ 신가영 ${ }^{2}$ · 설아영 ${ }^{3}$

'한림대학교 언어청각학부 청각언어연구소, ${ }^{2}$ 한림대학교 일반대학원 언어청각학과, ${ }^{3}$ 한림대학교 청각언어연구소

배경 및 목적: 이 연구는 한국의 발달성 난독 초등학생을 대상으로 단어해독력과 읽기유창성이 초등학교 저, 중, 고학년으로 가면서 일 반아동과 비교해 어떤 발달 특성을 보이는 지 살펴본다. 방법: 초등 저학년 20 명, 중학년 18 명, 고학년 20 명의 발달성 난독 아동과 학년, 지능, 듣기이해력이 일치되는 일반학생이 참여하였다. 단어해독 의미 유무와 자소-음소 일치도를 고려한 KOLRA 해독 검사 및 문단글 읽기 하위 과제를 개별적으로 실시한 후 분석하였다. 결과: 발달성 난독 아동은 단어해독의 경우, 초등 저학년에서 격차가 가장 컸고, 초등 고학년으로 가면서 격차가 줄어드는 모습을 보였다. 무의미낱말에서 더 큰 어려움이 관찰되었다. 유창성의 경우 10 초당 정확하게 읽은 음절수는 일반아동과의 격차가 계속 유지되었으나, 오류 음절률로 보았을 때 일반아동과의 격차가 줄어드는 경향도 관찰하였다. 논의 및 결론: 한국 발달성 난독 아동들도 음운 해독에서 약점을 보였고 저학년의 경우 무의미낱말해독에서 약점이 나타나 언어보편 적 특성을 확인할 수 있었다. 또한 읽는 속도에서의 차이도 한국의 발달성 난독 아동들에게 약점으로 작용할 것으로 보이므로 단어나 덩이글 읽기 속도에 대한 지원이 필요한 것으로 보인다. 음운성 및 표면성 난독증과 $\mathrm{PA}, \mathrm{RAN}$, 자소지식, 형태소인식력이 한국 발달성 난독아동의 해독력 및 읽기유창성과 어떤 연관성이 있는지 후속연구가 필요하다.

핵심어: 발달성 난독증, 한국어, 단어해독, 읽기유창성, 음운해독, 무의미단어

이 논문은 2013년 정부(교육부)의 재원으로 한국연구재단의 지원을 받아 수행된 연구(NRF-2013S1A5A2A03044158)이며, 한림대 교비연구 비 지원에 의해 이루어짐(HRF-201701-012).

\section{참고문헌}

김미배, 배소영(2011). 낱말읽기에서의 초등학생 음운해독력 발달. 언어청각장애연구, 16, 143-153.

김미배, 배소영(2012). 초등 읽기부진 아동의 읽기특성. 언어청각장애연구, 17, 565-581.

김애화, 김의정, 강은영(2016) 확인적 요인 분석을 활용한 연령별 읽기 구조에 대한 연구. 언어청각장애연구, 21, 631-641.

김애화, 김의정, 황민아, 유현실(2014). 읽기성취 및 읽기인지처리 능력 검사(RA-RCP). 서울: 학지사.

김애화, 박성희, 김주현(2010). 초등학생의 읽기유창성 특성 연구: 읽기유창성 발달 패턴 및 오류 유형 분석. 언어청각장애연구, 15, 43-55.

김영태, 홍경훈, 김경희, 장혜성, 이주연(2009). 수용·표현어휘력검사(REVT). 서울: 서울장애인종합복지관.

김용욱, 우정한, 신재한(2015). 난독증 연구에 대한 고찰. 특수교육저널: 이론과 실천, 16, 213-242.

김윤옥, 강옥려, 우정한, 변찬석(2015). 난독증 선별 체크리스트 표준화 및 한국 난독증 학생 통계추정 연구. 학습장애연구, 12, 21-45.

박혜원(2014). 한국 비언어지능검사 2판(K-CTONI-2). 서울: 마인드프레스.

배소영, 김미배, 윤효진, 장승민(2015). 한국어 읽기검사(KOLRA). 서울: 학지사.

안종복, 신명선, 권도하(2002). 정상 성인 및 아동의 구어 속도에 관한 연구. 음성과학, 9, 93-103.

윤효진(2015). 초등 저학년과 고학년의 읽기이해 예측 요인 연구. 언어청각장애연구, 20, 536-546.

윤효진(2016). 학령기 아동의 읽기이해 관련 요인: 단어재인정확도와 읽기유창성을 중심으로. 언어치료연구, 25, 109-118.

정부자(2009). 초등학교 저학년 읽기부진 아동의 읽기관련 변인에 관한 연구. 재활복지, 13, 313-327.

정종성(2015), 초등학교 1학년 아동의 자모 인식, 단어해독, 읽기 유창성 발달 양상 탐색. 초등교육연구, 28, 113-131.

Brock L. Eide, Fernette F. Eide (2013). 난독증 심리학(The dyslexia advantage: unlocking the hidden potential of the dyslexic brain, 정재석, 김수경, 박단비, 한석우 역). 서울: 시그마프레스. 
EBS뉴스(2014) 초등학생 5\%가 읽기 위험군. http://home.ebs.co.kr/ebsnews/menu1/newsAllView/10215253/H?eduNewsYn=N\&newsFldDetlCd= $\& \operatorname{brdcDt}=\& \mathrm{dtBtn}=\& \operatorname{srchStartDt}=\& \operatorname{srchEndDt}=\& \operatorname{srchType}=\& \operatorname{srchWords}=\& \operatorname{srchWords} 2=\& \mathrm{cPage}=705$ 